\title{
Potensi Pengembangan Peternakan Kambing Di Kabupaten Kepulauan Aru Provinsi Maluku
}

\author{
N.C. Tiven ${ }^{1 a}$, J.F. Salamena ${ }^{1}$, D. De Lima ${ }^{1}$, J.M. Tatipikalawan ${ }^{1}$, I.P. Siwa ${ }^{1}$ \\ ${ }^{1}$ Jurusan Peternakan Fakultas Pertanian Universitas Pattimura \\ aemail: nafly_tiven@yahoo.co.id
}

\begin{abstract}
Abstrak
Penelitian ini bertujuan untuk mengetahui potensi pengembangan peternakan kambing di Kabupaten Kepulauan Aru Provinsi Maluku. Penelitian ini merupakan penelitian deskriptif dengan metode survei.. Pengambilan sampel secara sengaja di Kecamatan Sir Sir dan Aru Tengah yang akan menjadi pilot project pengembangan ternak kambing. Hasil penelitian menunjukkan bahwa Kecamatan Sir Sir dan Aru Tengah, bila dilihat dari : (1) Potensi wilayah : sangat baik sebagai wilayah pengembangan ternak kambing; (2) Dari potensi peternak : usaha peternakan kambing masih dilakukan oleh peternak secara tradisional; (3) Dari potensi ekonomi : Rata-rata pendapatan yang diperoleh peternak kambing berada pada kisaran Rp.2.000.000-2.500.000/tahun, dengan nilai Return Cost Ratio (R/C) pada masing-masing kecamatan, yaitu 1,62 dan $1,80(\mathrm{R} / \mathrm{C}$ rasio $>1)$ sehingga menguntungankan dan layak dikembangkan. Dapat disimpulkan bahwa Kecamatan Sir Sir dan Kecamatan Aru Tengah Kabupaten Kepulauan Aru, sangat berpotensi sebagai tempat pengembangan peternakan kambing, bila dilihat dari potensi wilayah dan potensi ekonominya, sedangkan potensi peternaknya perlu ditingkatkan lagi.
\end{abstract}

Kata kunci: Potensi wilayah, Potensi peternak, Potensi ekonomi.

\section{Potential Development of Goat Livestock In the Aru Islands Regency, Maluku Province}

\begin{abstract}
This study aims to determine the potential development of goat livestock in Aru Islands District, Maluku Province. This research is a descriptive study with a survey method. The samples taken intentionally in Sir Sir and Aru Tengah Subdistricts, which will become a pilot project for the development of goats. The results showed that the Sir Sir and Aru Central Districts, when viewed from: (1) The potential of the region: very good for the development area of goat livestock; (2) The potential of farmers: goat farms are still carried out traditionally; (3) From economic potential: The average income obtained by goat farmers business in the range of Rp.2,000,000-2,500,000/year, with a Return Cost Ratio $(R / C)$ value in each sub-district, namely 1.62 and $1.80(R / C$ ratio $>1)$ so that it is profitable and feasible to be developed. It can be concluded that Sir Sir and Aru Tengah Subdistricts, Aru Islands District, have great potential as a place for developing goat farms, if viewed from the aspect of regional potential and economic potential, while the potential of the farmers needs to be increased.
\end{abstract}

\section{Keywords: Regional potential, Farmerss potential, Economic potential.}

\section{Pendahuluan}

Di Maluku, dengan adanya pembangunan dan rencana pengoperasian Kilang Gas Blok Masela, yang diperkirakan akan menyerap $\pm 380,000$ tenaga kerja, selain dikuatirkan akan mempengaruhi kultur, mencaplok tanah-tanah pertanian menjadi lahan pabrik, pemukiman dan pusat bisnis, tetapi dapat dijadikan peluang pengembangan peternakan khususnya dalam menghasilkan komoditas produk yang berkualitas. Hal ini juga ditunjang dengan keseriusan kebijakan pemerintah Provinsi Maluku dengan program yang tengah diusahakan agar seluruh logistik Blok Masela harus dipasok dari dalam Provinsi Maluku, terutama logistik yang menyangkut daging segar dan berkualitas. Hal ini membutuhkan akselerasi pembangunan peternakan yang harus terus digalakkan, 
dengan lebih mendorong kegiatan peternakan kearah suatu kegiatan agribisnis, sehingga tidak berkutat hanya sebagai usaha sampingan dan identik dengan usaha masyarakat kecil di pedesaan.

Jargaria atau Kepulauan Aru merupakan daratan ekologi Papua yang secara administrasi berada di Provinsi Maluku. Secara geografis, Kabupaten Kepulauan Aru terletak diantara $5^{\circ}-8^{\circ}$ Lintang Selatan dan $133,5^{\circ}-136,5^{\circ}$ Bujur Timur. Luas wilayah Kabupaten Kepulauan Aru adalah $\pm 55.270,22$ $\mathrm{km}^{2}$ dengan luas daratan hanya $\pm 6.426,77 \mathrm{~km}^{2}$ $(11,63 \%)$ (Jaya et al., 2016), terdiri dari 10 kecamatan dengan \pm 837 pulau, yang berpenghuni hanya 59 pulau, sedangkan 778 merupakan pulau tidak berpenghuni (BPS, 2018). Ada 5 pulau diantaranya yang relatif besar, yaitu Pulau Wokam, Kobror, Maekor,
Trangan dan Kola (Kartohardjono et al., 2015), sedangkan sisianya umumnya merupakan pulau-pulau berukuran kecil $\left(<2.000 \mathrm{~km}^{2}\right)$.

Selain jumlah pulau kecil relatif banyak, yang dapat menjadi lahan peternakan dan sumber pakan hijauan, potensi sumberdaya laut di Kabupaten Kepulauan Aru juga sangat melimpah, baik perikanan tangkap dan budidaya serta budidaya rumput laut, ditunjang dengan beberapa industri pengolahan perikanan, yang dapat menjadi sumber pakan konsentrat protein tinggi. Selain itu tren perkembangan ternak juga cenderung meningkat, khususnya pada ternak sapi, kambing, babi dan itik, serta ayam kampung, sedangkan ayam petelur dan ayam pedaging belum diusahakan secara komersil.

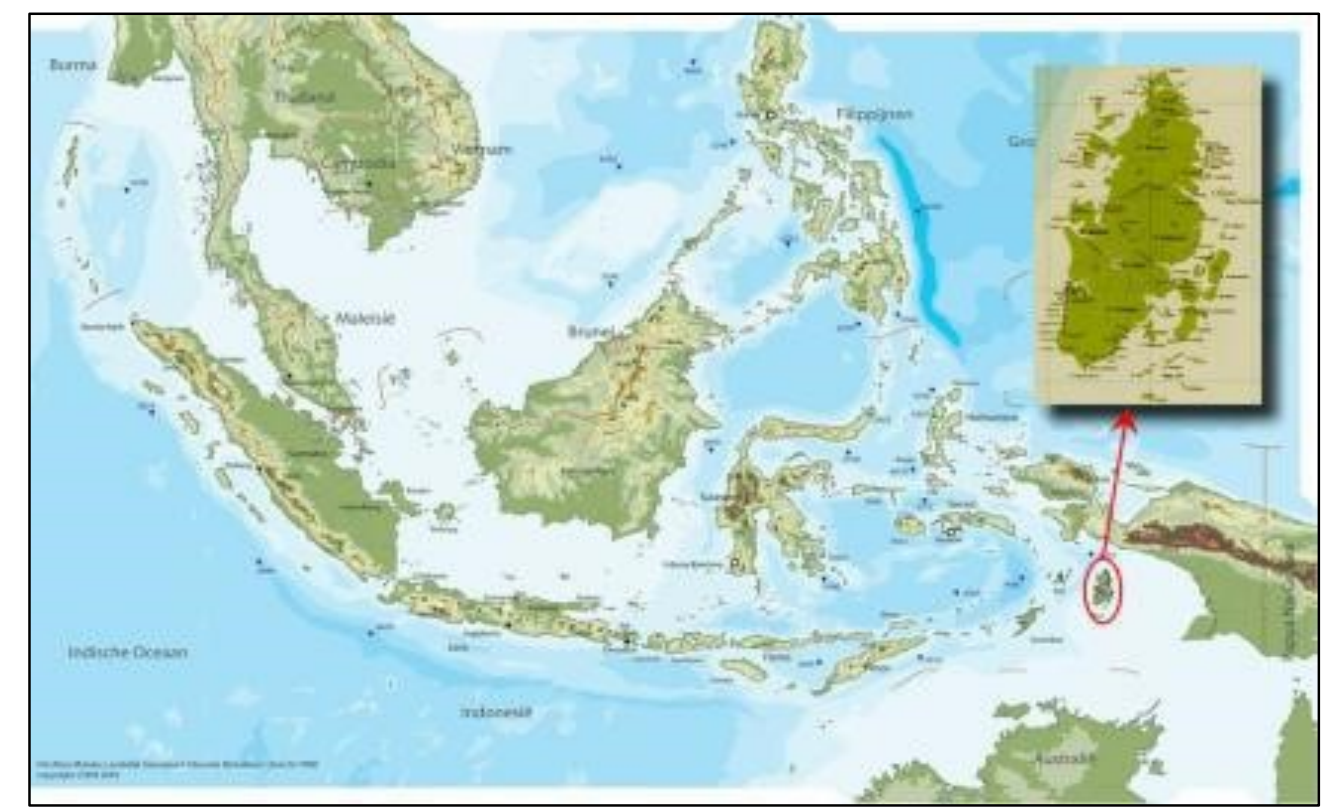

Gambar 1. Letak Kabupaten Kepulauan Aru dalam Wilayah Negara Kesatuan Republik Indonesia (Sumber : Anonim, 2016).

Tabel 1. Perkembangan Populasi Ternak Di Kabupaten Kepulauan Aru Tahun 2014-2016.

\begin{tabular}{lrrrrr}
\hline \multicolumn{1}{c}{ Jenis Ternak } & 2013 & 2014 & 2015 & 2016 & 2017 \\
\hline Ayam Petelur & - & - & - & - & - \\
Ayam Pedaging & - & - & - & - & - \\
Itik & 130 & 169 & 522 & 358 & 395 \\
Babi & 200 & 248 & 681 & 357 & 4.376 \\
Sapi & 347 & 417 & 487 & 507 & 577 \\
Kambing & 978 & 984 & 1.014 & 1.065 & 1.159 \\
Ayam Kampung & 9.960 & 9.971 & 10.136 & 10.147 & 7.329 \\
\hline
\end{tabular}

Sumber : BPS (2018). 


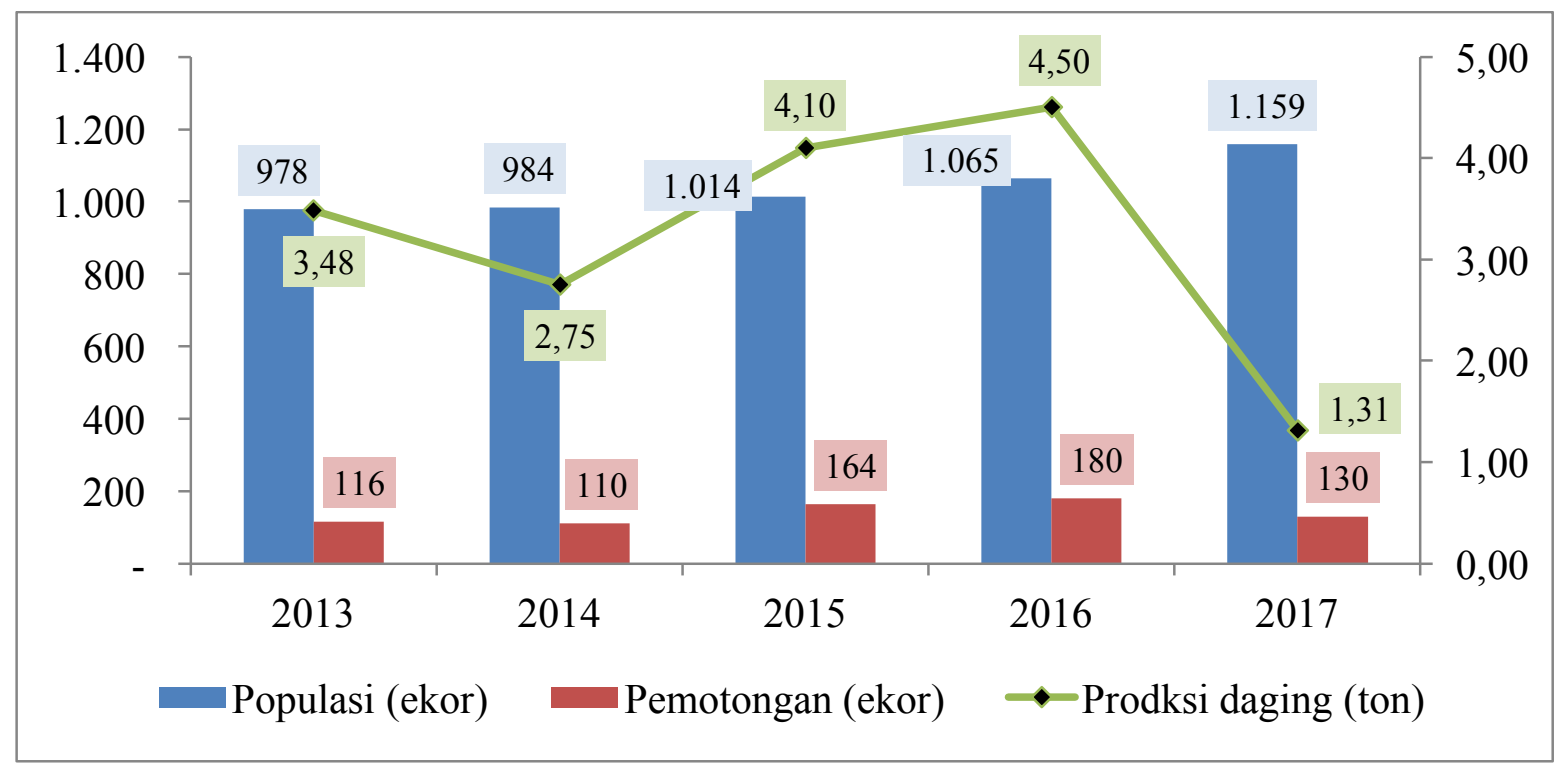

\section{Gambar 2. Populasi, pemotongan dan produksi daging ternak kambing di Kabupaten Kepulauan Aru Tahun 2013-2017 (Sumber : BPS, 2018).}

Bila dilihat dari populasi ternak, maka ternak kambing sangat berpotensi untuk dikembangkan, karena salah satu indikator peningkatan pembangunan subsektor peternakan dapat dilihat dengan bertambahnya populasi ternak pada komoditas yang ada.

Ternak kambing merupakan komponen penting dalam usaha tani rakyat karena pemeliharaan kambing dengan skala kecil dapat membantu subsistensi ekonomi rakyat dengan pemanfaatan sumber daya alam yang tersedia disekitar (Zulfanita, 2011). Potensi ini dapat digunakan untuk pengembangan peternakan, khususnya peternakan kambing.

Pemerintah Kabupaten Kepulauan Aru sendiri telah mencoba memetakan area pengembangan peternakan kambing di Kecamatan Sir Sir dan Kecamatan Aru Tengah, yang diproyeksi menjadi pilot project pengembangan ternak kambing. Berkaitan dengan itu, maka penelitian ini bertujuan untuk mengetahui potensi wilayah, potensi peternak dan potensi usaha serta model pengembangan peternakan kambing di kedua wilayah tersebut. Hasil penelitian ini diharapkan akan menjadi bagian penting bagi perencanaan dan kebijakan yang akan diambil untuk pengembangan peternakan kambing yang dapat meningkatkan pendapatan dan kesejahteraan petani peternak, yang berdampak pada pemberdayaan masyarakat dan pengentasan kemiskinan serta meningkatkan pendapatan asli daerah.

\section{Materi dan Metoda}

Penelitian ini dilakukan pada Bulan Juni 2016 di Desa Goda Goda Kecamatan Sir Sir dan Desa Benjina Kecamatan Aru Tengah Kabupaten Kepulauan Aru yang direncanakan akan menjadi pilot project pengembangan ternak kambing. Penelitian ini merupakan penelitian deskriptif dengan metode survey. Data yang dikumpulkan meliputi data primer (observasi lapangan maupun wawancara dengan menggunakan kuesioner) dan data sekunder (data dari instansi terkait serta data pelaporan dan literatur). Data karakteristik peternak dianalisis secara deskritif. Untuk mengetahui komposisi botani, produksi bahan segar dan bahan kering serta daya tampung, digunakan metode Halls et al. (1964) dalam Manu (2013). Data potensi individu peternak dianalisis menggunakan metode skoring dan pembobotan (Deptan, 2003). Selain itu dihitung pula pendapatan peternak kambing.

\section{Hasil dan Pembahasan Potensi Wilayah}

Keadaan umum wilayah kajian di Kecamatan Sir Sir dan Kecamatan Aru Tengah, dapat dilihat pada tabel di bawah ini.

Dari Tabel 2, dapat dilihat bahwa tingkat kepadatan penduduk pada kedua kecamatan sangat rendah, terlihat dari besarnya areal yang belum dimanfaatkan, yang masing-masing baru mencapai $99,86 \%$ dan $88,07 \%$, sehingga tersedia areal untuk 
membangun peternakan yang jauh dari perumahan penduduk.

Kebanyakan areal yang belum dimanfaatkan ini berupa padang alam yang relati luas yang dapat menampung ternak kambing antara 111 ribu sampai 290 ribu ekor ternak kambing dewasa. Di dalam padang penggembalaan alam ini terdapat berbagai jenis hijauan pakan, yang apabila ditambah dengan limbah pertanian tanaman pangan, maka jumlah bahan keringnya lebih dari 39.000 sampai 111.000 ton/tahun, yang dapat menampung sebanyak 102 ribu sampai 290 ribu ekor ternak kambing dewasa.

\section{Potensi Sumber Daya Peternak Karakteristik Peternak}

Karakteristik peternak kambing di Kecamatan Sir Sir dan Kecamatan Aru Tengah, dapat dilihat pada tabel di bawah ini.

Peternak kambing di Kecamatan Sir Sir dan Kecamatan Aru Tengah sebagian besar berada pada usia produktif. Pada usia tersebut peternak diprediksikan berada pada usia yang matang dalam berpikir dan bertindak, masih tangguh dalam bekerja dan rasional dalam pengambilan keputusan.
Tingkat pendidikan peternak di Kecamatan Sir Sir relatif memadai, yaitu sebagian besar tamat SMP (44\%) dan SMA (33\%), sedangkan di Kecamatan Aru Tengah tingkat pendidikan peternak kambing kurang memadai, yaitu cukup banyak yang tidak tamat SD (20\%) dan SMP (40\%). Pendidikan tertinggi peternak pada Kecamatan Aru Tengah hanya tamatan SMP (20\%). Rendahnya tingkat pendidikan mungkin disebabkan oleh rendahnya tingkat ekonomi keluarga yang tidak mampu membiayai pendidikan ke jenjang lebih tinggi. Rendahnya tingkat pendidikan berdampak pada rendahnya daya serap peternak terhadap informasi dan teknologi yang baru, sehingga usaha-usaha yang mengarah pada peningkatan produksi ternak dan pendapatan akan bergerak secara lambat, yang terlihat dari usaha peternakan kambing yang masih bersifat tradisional. Kondisi ini lebih diperparah bila peternak tidak berusaha untuk mengikuti pendidikan informal berupa pelatihan dan penyuluhan dalam bidang peternakan guna peningkatan kapasitas peternak. Model Sekolah Lapang merupakan model yang paling tepat dalam peningkatan kapasitas peternak.

Tabel 2. Keadaan Umum Kecamatan Sir Sir Dan Kecamatan Aru Tengah Kabupaten Kepulauan Aru

\begin{tabular}{|c|c|c|}
\hline \multirow{2}{*}{ Keadaan Umum } & \multicolumn{2}{|c|}{ Kecamatan } \\
\hline & Sir Sir & Aru Tengah \\
\hline Jumlah jiwa* & 2.882 orang & 13.667 orang \\
\hline Kepadatan* & 5 jiwa $/ \mathrm{km}^{2}$ & 9 jiwa $/ \mathrm{km}^{2}$ \\
\hline Topgrafi* & Dataran rendah $(0-5 \mathrm{dpl})$ & Dataran rendah $(0-9 \mathrm{dpl})$ \\
\hline Sumber air* & $\begin{array}{l}\text { Air hujan, Mata air, Sumur } \\
\text { terlindung }\end{array}$ & Mata air, Sumur terlindung \\
\hline Luas wilayah* & $528,39 \mathrm{~km}^{2}(52.839 \mathrm{ha})$ & $1.372,06(137.206 \mathrm{ha})$ \\
\hline Telah Dimanfaatkan* & $0,73 \mathrm{~km}^{2}(73,0 \mathrm{ha})$ & $232,25 \mathrm{~km}^{2}(23.225 \mathrm{ha})$ \\
\hline Belum dimanfaatkan* & $527,66 \mathrm{~km} 2(52.766 \mathrm{ha})$ & $1.139,81(1.139,81 \mathrm{ha})$ \\
\hline Luas padang alam** & $26.419,50$ ha & $68.603,00$ ha \\
\hline Kapasitas tampung** & $\begin{array}{l}\text { 18.605,28 UT (111.631 ekor } \\
\text { kambing dewasa) }\end{array}$ & $\begin{array}{l}48.311,97 \text { UT (289.871 ekor } \\
\text { kambing dewasa) }\end{array}$ \\
\hline Komposisi botani** & \multicolumn{2}{|c|}{$\begin{array}{l}\text { Rumput Pahit (Paspalum conjugatum); Kolonjono (Ponicum muticum); } \\
\text { Rumput bahia (Paspalum notatun) dan Rumput Bermuda (Cynodon } \\
\text { dactylon) serta Colopo (Colopogonium mucunoides). }\end{array}$} \\
\hline Jumlah BK ${ }^{* *}$ & $38.443,81$ ton/tahun & $110.164,38$ ton/tahun \\
\hline Kapasitas tampung** & $\begin{array}{l}\text { 16.851,64 UT/tahun (101.109,84 } \\
\text { ekor kambing dewasa/tahun) }\end{array}$ & $\begin{array}{l}\text { 48.290,17 UT/tahun }(289.741,02 \\
\text { ekor kambing dewasa/tahun }\end{array}$ \\
\hline
\end{tabular}

Sumber : *BPS (2018); ** Data primer. 
Tabel 3. Karakteristik Peternak Kambing Di Kecamatan Sir Sir Dan Kecamatan Aru Tengah Kabupaten Kepulauan Aru.

\begin{tabular}{|c|c|c|c|}
\hline \multirow{2}{*}{ No. } & \multirow{2}{*}{ Karakteristik peternak } & \multicolumn{2}{|c|}{ Persentase } \\
\hline & & Sir Sir & Aru Tengah \\
\hline \multirow[t]{3}{*}{1.} & Umur Peternak & & \\
\hline & $22-55$ tahun & 100,0 & 80,0 \\
\hline & $>55$ tahun & - & 20,0 \\
\hline \multirow[t]{7}{*}{2.} & Pendidikan Formal & & \\
\hline & Tidak tamat SD & - & 20,0 \\
\hline & Tamat SD & 22,2 & 20,0 \\
\hline & Tidak tamat SMP & - & 40,0 \\
\hline & Tamat SMP & 44,5 & 20,0 \\
\hline & Tidak tamat SMA & - & - \\
\hline & Tamat SMA & 33,3 & - \\
\hline \multirow[t]{3}{*}{3.} & Pendidikan Non Formal & & \\
\hline & Pernah mengikuti pelatihan & - & 60,0 \\
\hline & Tidak pernah mengikuti pelatihan & 100,0 & 40,0 \\
\hline \multirow[t]{4}{*}{4.} & Pekerjaan Pokok & & \\
\hline & Petani & 55,6 & 100,0 \\
\hline & Nelayan & 33,3 & - \\
\hline & Pedagang & 11,1 & - \\
\hline \multirow[t]{3}{*}{5.} & Pekerjaan sampingan & & \\
\hline & Peternak & - & - \\
\hline & Peternak sekaligus nelayan & 100,0 & 100,0 \\
\hline \multirow[t]{4}{*}{6.} & Anggota Keluarga & & \\
\hline & $2-5$ orang & 77,8 & 20,0 \\
\hline & $6-8$ orang & 22,2 & 80,0 \\
\hline & $>8$ orang & - & - \\
\hline \multirow[t]{4}{*}{7.} & Pengalaman beternak (tahun) & & \\
\hline & $1-10$ & - & - \\
\hline & $11-20$ & 100,0 & 100,0 \\
\hline & $21-30$ & - & - \\
\hline
\end{tabular}

Pekerjaan pokok sebagian besar peternak di Kecamatan Sir Sir $(55,56 \%)$ dan Aru Tengah (100\%) adalah petani tanaman pangan dan sayur-sayuran, yang limbahnya dapat dimanfaatkan sebagai pakan ternak kambing. Usaha peternakan kambing kurang mendapat perhatian, karena peternakan hanya sebagai sambilan, itupun bercampur dengan pekerjaan sebagai nelayan. Padahal usaha peternakan kambing dapat memberi tambahan pendapatan serta menolong peternak dalam mengatasi kebutuhan ekonomi keluarga yang mendesak, bila diusahakan secara baik.

Peternak kambing di Kecamatan Sir Sir sebagian besar (77,8\%) jumlah anggota keluarganya berada pada kisaran 2-5 orang, sedangkan di Kecamatan Aru Tengah sebagian besar $(80 \%)$ berada pada kisaran 6-8 orang. Banyaknya anggota keluarga dalam suatu rumah tangga peternak umumnya menunjukkan besarnya beban dan tanggungjawab untuk memenuhi kebutuhan anggota keluarganya, tetapi dapat pula merupakan aset petani dalam melaksanakan usaha pertanian sebagai tenaga kerja keluarga. Ketersediaan anggota keluarga sangat membantu dalam merawat dan mengurus ternak kambing yang dipelihara.

Hasil penelitian menunjukkan bahwa peternak telah berpengalaman dalam memelihara ternak kambing ( $>10$ tahun), sehingga dapat menjadi salah satu potensi dalam pengembangan ternak kambing, yang akan dijadikan sebagai mitra dalam kegiatan pengembangan usaha peternakan kambing melalui model pemberdayaan pada kedua kecamatan tersebut. Pengalaman peternak kambing yang terus diperkaya melalui proses belajar pada kegiatan penyuluhan dan pelatihan serta semakin sering diterapkan, akan berdampak positif dalam proses pengelolaan usaha peternakan kambing yang lebih baik. 
Tabel 4. Kepemilikian Ternak Kambing Di Kecamatan Sir Sir Dan Aru Tengah Kabupaten Kepulauan Aru.

\begin{tabular}{|c|c|c|c|}
\hline No. & Uraian & Sir Sir & Aru Tengah \\
\hline \multirow[t]{3}{*}{1.} & Kepemilikan ternak (\%) & & \\
\hline & $4-10$ ekor & 75 & 80 \\
\hline & $>10$ ekor & 25 & 20 \\
\hline \multirow[t]{3}{*}{2} & Alasan pemeliharaan (\%) & & \\
\hline & Tabungan & 88 & 80 \\
\hline & Menambah Pendapatan & 12 & 20 \\
\hline \multirow[t]{6}{*}{3.} & Sistem Pemeliharaan dan produksi (\%) & & \\
\hline & Intensif & - & - \\
\hline & Semi intensif & - & 20 \\
\hline & Ekstensif & 100 & 80 \\
\hline & Pastoral & - & - \\
\hline & Agropastoral & 100 & 100 \\
\hline 4. & Lama waktu kerja (jam/hari) & 4,50 & 3,07 \\
\hline
\end{tabular}

\section{Kepemilikan Ternak}

Kepemilikan ternak kambing di Kecamatan Sir Sir dan Kecamatan Aru Tengah, dapat dilihat pada tabel di bawah ini.

Sebagian besar jumlah kepemilikan ternak di Kecamatan Sir Sir dan Kecamatan Aru Tengah berada pada kisaran 4-10. Ada beberapa peternak yang memiliki ternak kambing $>10$ ekor (tepatnya $>40$ ekor), sehingga dapat dijadikan sebagai contoh beternak kambing serta sebagai sumber bibit.

Sebagian besar alasan peternak memelihara ternak kambing adalah sebagai tabungan, dimana ttt ternak kambing dapat dijual untuk memenuhi kebutuhan hidup keluarga yang mendesak, misalnya untuk pendidikan anak dan acara keagaman.

Ternak kambing dipelihara secara ekstensif (tanpa menggunakan kandang), dengan sistem produksi agropastoral artinya bahwa peternak selain menggunakan hijauan yang tersedia di padang pengembalaan juga telah memanfaatkan limbah pertanian tanaman pangan untuk pakan, tanpa teknologi pengolahan.

Tenaga kerja yang digunakan sebagian besar adalah tenaga kerja keluarga, dimana seluruh pengelolaan ternak kambing dijalankan oleh anggota keluarga. Dalam hal ini kepala keluarga memiliki peran utama dalam memelihara ternak sehingga curahan waktu kerja kepala keluarga lebih banyak dibandingkan anggota keluarga lainnya. Rata- rata waktu kerja per keluarga berkisar 3-5 jam per hari, sedangkan sisanya digunakan untuk mengerjakan usahatani, nelayan dan usaha lainnya di luar usaha ternak kambing.

\section{Potensi Individu Peternak}

Peternak individu peternak kambing di Kecamatan Sir Sir dan Kecamatan Aru Tengah, dapat dilihat pada Tabel 5 .

Potensi dasar peternak kambing di Kecamatan Sir Sir sebagian besar berada pada kategori rendah (89\%), sedangkan di Kecamatan Aru Tengah berada pada kategori sedang (60\%) dan tinggi (40\%). Komponen potensi dasar ini yaitu pendidikan formal dan non formal, kemampuan baca dan tulis, intensitas komunikasi, lama usaha dan pengalaman. Melihat komponenya, mungkin potensi dasar pada kedua kecamatan ini lebih dipengaruhi oleh lama usaha dan pengalaman peternak dalam mengembangkan usaha peternakan kambing. Semakin tinggi lama usaha, semakin tinggi pula pengalaman seseorang di dalam mengembangkan usahanya.

Potensi penguasaan teknologi peternak kambing di Kecamatan Sir Sir berada pada kategori rendah $(100 \%)$, sedangkan di Kecamatan Aru Tengah cenderung lebih baik dan merata, yaitu berada pada kategori rendah (40\%), sedang (40\%) dan tinggi $(20 \%)$. 
Tabel 5. Potensi Individu Peternak Kambing di Kecamatan Sir Sir dan Kecamatan Aru Tengah Kabupaten Kepulauan Aru.

\begin{tabular}{llcccc}
\hline \multirow{2}{*}{ Potensi peternak } & \multirow{2}{*}{ Kecamatan } & \multicolumn{4}{c}{ Persentase } \\
\cline { 3 - 6 } & & Rendah & Sedang & Tinggi & Total \\
\hline 1. Potensi dasar & Sir Sir & 89 & 0 & 11 & 100 \\
& Aru Tengah & 0 & 60 & 40 & 100 \\
2. Potensi penguasaan teknologi & Sir Sir & 100 & 0 & 0 & 100 \\
& Aru Tengah & 40 & 40 & 20 & 100 \\
3. Potensi penyediaan input produksi & Sir Sir & 100 & 0 & 0 & 100 \\
& Aru Tengah & 80 & 20 & 0 & 100 \\
4. Potensi penyediaan tenaga kerja & Sir Sir & 0 & 67 & 33 & 100 \\
& Aru Tengah & 20 & 40 & 40 & 100 \\
\hline
\end{tabular}

Komponen potensi penguasaan teknologi ini yaitu kemampuan dalam teknologi pakan, pencegahan dan penanggulangan penyakit, seleksi pejantan dan induk. Peternak relatif belum dapat meramu dan menyimpan pakan, pencegahan dan pengendalian penyakit serta seleksi ternak. Perlu peran Dinas Pertanian melalui kegiatan penyuluhan dan pelatihan untuk dapat meningkatkan potensi individu peternak. Peternak juga harus membuka diri mengadopsi teknologi untuk mengembangkan usahanya.

Potensi penyedian input produksi di Kecamatan Sir Sir dan Aru Tengah berada dalam kategori rendah, yang masing-masing mencapai $100 \%$ dan $80 \%$. Komponen potensi penyedian input produksi ini terdiri dari kemampuan memiliki kandang, skala usaha dan modal usaha. Rendahnya potensi penyediaan input produksi disebabkan karena peternak tidak memiliki kandang, sehingga ternak kambing dibiarkan mencari makan sendiri. Peternak juga masih menggunakan modal pribadi yang sangat kecil, karena belum mampu mengakses berbagai lembaga pemerintah maupun swasta penyedia modal serta lebih banyak menunggu bantuan pemerintah.

Potensi penyediaan tenaga kerja pada usaha peternakan kambing di Kecamatan Sir Sir berada pada kategori sedang (67\%) dan tinggi (33\%), sedangkan pada Kecamatan Aru Tengah relatif lebih merata, yang berada pada kategori sedang (40\%) dan tinggi (40\%). Hasil ini menunjukkan bahwa tenaga kerja sangat tersedia dan mampu mengerjakan seluruh pekerjaan yang terkait dengan pengelolaan usaha ternak kambing. Dalam usaha peternakan kambing tenaga kerja keluarga yang curahan waktu kerja tinggi dilakukan oleh peternak sebagai kepala keluarga dan tenaga kerja wanita disesuaikan dengan curahan waktu kerja peternak, kebiasaannya waktu kerja pagi dilakukan oleh peternak (kepala keluarga) untuk mengelola usaha peternakan kambing dan tenaga kerja perempuan digunakan apabila tenaga kerja laki-laki mengerjakan pekerjaan lainnya. Tenaga kerja keluarga harus dimanfaatkan dengan baik, karena dapat mengurangi biaya tenaga kerja.

\section{Potensi Ekonomi}

\section{Pemasaran Ternak Kambing}

Pemasaran ternak kambing di

Kecamatan Sir Sir dan Kecamatan Aru Tengah

Kabupaten Kepulauan Aru, dapat dilihat pada Tabel 6.

Ternak kambing yang di jual adalah ternak hidup (100\%), sehingga tidak ada produk olahan lain dari ternak kambing. Padahal bila produk olahan bisa digalakkan, maka peternak akan menikmati keuntungan yang lebih besar. Harga jual ternak kambing sangat bervariasi antara kedua kecamatan ini, yang dipengaruhi oleh jantan/betina, kondisi keragaan kambing serta momentum yang pas pada saat pembelian, misalnya pada hari-hari besar keagamaan (Idul Adha). Cara pemasaran ternak kambing juga bervariasi, ada pedagang luar daerah yang langsung mendatangi peternak, ada juga peternak memasarkan langsung ke konsumen. Cara pemasaran ternakni juga sangat mempengaruhi besaran harga jual ternak kambing. Cara pemasaran ternak ini juga sekaligus dipengaruhi oleh pedagang yang dapat berfungsi langsung sebagai penentu/pemberi informasi tentang harga jual ternak kambing. 
Tabel 6. Pemasaran ternak kambing di Kecamatan Sir Sir dan Kecamatan Aru Tengah Kabupaten Kepulauan Aru.

\begin{tabular}{lcc}
\hline \multicolumn{1}{c}{ Komponen Pemasaran } & Sir Sir & Aru Tengah \\
\hline 1. Kisaran harga jual (Rp/ekor): & & \\
Jantan & $700.000-800.000$ & $600.000-800.000$ \\
Betina & $800.000-1.000 .000$ & $500.000-600.000$ \\
2. Bentuk Produksi : & 100 & 100 \\
Ternak Hidup & - & - \\
Daging & 25 & 80 \\
3. Cara Pemasaran : & 75 & 20 \\
Pedagang luar desa & & 60 \\
Langsung ke konsumen & 25 & 40 \\
4. Informasi Harga Jual : & 75 & \\
Pedagang & & \\
Sesama Peternak & & \\
\hline
\end{tabular}

\section{Pendapatan}

Pendapatan peternak kambing di Kecamatan Sir Sir dan Kecamatan Aru Tengah Kabupaten Kepulauan Aru dapat dilihat pada Tabel 7.

Penerimaan usahatani adalah nilai uang yang diterima dari penjualan produksi usahatani. Besarnya penerimaan usahatani ternak dalam setahun produksi ditentukan dari nilai penjualan ternak, nilai ternak yang dikonsumsi keluarga dan pertambahan nilai inventaris (Soekartawi, 1995). Hasil penelitian menunjukkan bahwa rata-rata penerimaan usaha peternakan kambing berkisar antara 5-6 juta/peternak/tahun Dengan demikian fungsi ternak kambing sangat penting dalam memenuhi kebutuhan ekonomi keluarga. Hal ini sejalan dengan tujuan pemeliharaan ternak kambing adalah untuk tabungan yang sewaktuwaktu akan dijual dan sebagai penambah pendapatan keluarga. Penerimaan peternak hanya diperoleh dari hasil penjualan ternak kambing, sedangkan produk ikutan lain seperti kotoran belum dijual. Hal ini disebabkan karena kurangnya pengetahuan dari peternak, bahwa produk sampingan ternak dapat menghasilkan penerimaan tambahan.

Pengeluaran terbesar adalah untuk biaya pakan $(55,97 \%)$, sedangkan yang terkecil adalah biaya obat-obatan $(0,14)$. Pendapatan merupakan hasil berupa uang atau hasil material lain yang dicapai dari penggunaan kekayaan atau jasa manusia secara bebas. Dengan kata lain pendapatan adalah selisih antara seluruh penerimaan yang diperoleh dengan biaya-biaya yang dikeluarkan oleh peternak (Rasyaf, 2003). Rata-rata pendapatan yang diperoleh peternak kambing berada pada kisaran 2-2,5 juta/peternak/tahun. Pendapatan peternak ini dapat lebih besar lagi, bila peternak tahu memanfaatkan hasil ikutan (kotoran) dari ternak. Dari nilai penerimaan dan pengeluaran, maka dapat diketahui nilai Return Cost Ratio (R/C) pada masing-masing kecamatan, yaitu 1,62 dan 1,80 ( $\mathrm{R} / \mathrm{C}$ rasio $>1)$, sehingga dapat dikatakan bahwa usaha peternakan kambing menguntungankan bagi peternak sehingga layak dikembangkan. Hasil ini menunjukkan bahwa sebagai bagian dari pelengkap mata pencaharian pokok, usaha peternakan kambing cukup memberikan sumbangan terhadap pendapatan keluarga peternak.

\section{Lokasi dan Pola Pengembangan}

Kedua kecamatan ini mempunyai potensi yang sama sebagai lokasi pengembangan ternak kambing. Hanya saja bila dilihat dari beberapa segi, antara lain infrastruktur transportasi, jarak dengan ibukota kabupaten, potensi individu peternak serta kemungkinan tersedianya pakan sumber protein, maka usaha peternakan kambing ini lebih layak dikembangkan di Kecamatan Aru Tengah pada Desa Benjina, sedangkan pengembangan pada tahap berikutnya dapat dilakukan di Kecamatan Sir Sir pada Desa Goda Goda.

Pengembangan peternakan kambing hendaknya diarahkan pada Village Breeding Centre atau Pembibitan Ternak Rakyat (PTR), dengan tujuan menghasilkan bibit kambig dengan mutu genetik yang unggul (elite stock), sehingga dapat menjamin ketersediaan populasi ternak untuk menjawab swasembada daging nasional. 
Tabel 7. Komponen pendapatan peternak kambing di Kecamatan Sir Sir dan Kecamatan Aru Tengah Kabupaten Kepulauan Aru.

\begin{tabular}{lrrrr}
\hline \multicolumn{1}{c}{ Komponen } & \multicolumn{1}{c}{ Sir Sir } & \multicolumn{1}{c}{ Aru Tengah } & $\%$ \\
\hline 1. Penerimaan : & 5.825 .000 & & 6.250 .000 & \\
2. Pengeluaran : & $3.592 .812,50$ & & 3.477 .600 & \\
Pakan & $2.010 .937,50$ & 55,97 & 1.856 .250 & 53,38 \\
Tenaga Kerja & 1.546 .875 & 43,05 & 1.608 .750 & 46,26 \\
Peralatan & 30.000 & 0,84 & 7.000 & 0,20 \\
Obat-obatan & 5.000 & 0,14 & 5.600 & 0,16 \\
3. Pendapatan & $2.232 .187,50$ & & 2.772 .400 & \\
4. R/C Ratio & 1,62 & & 1,80 & \\
Tipologi Usaha & $31,96 \%$ & & (Usaha sampingan) & \\
\hline
\end{tabular}

Pengembangan Pembibitan Rakyat (PTR) kambing akan dilakukan melalui pendekatan agribisnis dengan pola pembibitan sistem dua strata. Strata pertama adalah terdiri dari Unit Pelaksana Teknis Pembibitan (UPTP) milik Pemerintah Kabupaten Kepulauan Aru, yang fungsi menghasil bibit kambing unggul (elite stock) untuk nantinya diperbanyak (multiplier stock) oleh kelompok-kelompok peternak strata kedua. Jumlah ternak pada strata pertama (elite stock) dipertahankan sebanyak 250 ekor (50 jantan dan 200 betina). Jadi strata kedua adalah kelompok yang memperbanyak ternak (multiplier stock) dan mengkomersilkan ternak (commercial stock). Sistem pembibitan dua strata ini akan dilakukan secara terbuka (open breeding scheme) dengan pencatatan (recording) yang tepat, sehingga dapat mencegah terjadi silang dalam (inbreeding). Selanjutnya untuk commercial stock, dapat dijual dalam bentuk ternak hidup berupa ternak bibit, ternak penggemukan untuk yang afkir, maupun dalam bentuk olahan, seperti stock daging beku.

Untuk menunjang keberhasilan pengembangan PTR ini menjadi suatu agribisnis peternakan yang menguntungkan, maka aspek-aspek pendukung lainnya yang terkait dengan produktivitas ternak, pasca panen, peningkatan kapasitas sumber daya manusia, sarana prasarana dan infrastruktur pendukung, sosial ekonomi usaha ternak, dan sampai pada regulasi perlu adakan.

\section{Kesimpulan}

Kecamatan Sir Sir dan Kecamatan Aru Tengah Kabupaten Kepulauan Aru, sangat berpotensi sebagai tempat pengembangan peternakan kambing, bila dilihat dari segi potensi wilayah dan potensi ekonominya, sedangkan potensi peternaknya perlu ditingkatkan lagi.

\section{Ucapan Terima Kasih}

Ucapan terima kasih disampaikan kepada semua pihak yang ikut berperan serta dalam penelitian ini, antara lain Bappeda Kabupaten Kepulauan Aru yang telah mendanai seluruh penelitian ini, serta temanteman peneliti Jurusan Peternakan Fakultas Pertanian Universitas Pattimura.

\section{Daftar Pustaka}

Anonim. (2016). Kepulauan Aru; Hadirkah 'Kesehatan' di Sana? https://www.kompasiana. com/adl/573915b20f9773f90d59250c/k epulauan-aru-hadirkah-kesehatan-disana?page $=$ all (Diakses : 5 April 2019).

BPS. (2018). Kabupaten Kepulauan Aru Dalam Angka 2018. Badan Pusat Statistik Kabupaten Kepulauan Aru. Dobo.

Deptan. (2003). Pedoman Analisis Potensi Peternak. Direktorat Pengembangan Peternakan-Departemen Pertanian. Jakarta.

Endang Sujana, Heni Indrijani, Iwan Setiawan \& Asep Anang. (2014). "Produktivitas Itik Rambon Petelur Pada Pemeliharaan Minim Air", Prosiding Seminar Nasional Peternakan Berkelanjutan 6 . 10-11 November, Bandung, Indonesia, pp. 150-153.

Jaya, A. F., D. Bhatara \& S. Palupi. (2016). Potret Karst Kepulauan Aru Maluku, 
Indonesia. Forest Watch Indonesia \& Lawalata IPB. p. 10.

Kartohardjono, A., H. K. Buwono \& B. Al Hanif. (2015). Studi Kebutuhan Pelabuhan Dan Tinjauan Teknis Terhadap Kondisi Perairan Daerah Kepulauan Aru. Konstruksia 7(1): 7787.

Kumar, P., \& Mishra, H. N (2004), Mango soy fortified set yoghurt: effect of stabilizer addition on physicochemical, sensory and textural properties, J.Food Chem., $87: 501-507$.

Manu, A. E. (2013). Produktivitas Padang Penggembalaan Sabana Timor Barat. Pastura 3(1): 25-29.
Oberman, H (1985), Fermented Milks, In Microobiology of Fermented Foods. Vol.1. Edited By J.B. Wood, Elsevier Appplied Science Publishers, New York. 167-190.

Rasyaf, M. (2003). Beternak Ayam Pedaging. PenebarSwadaya. Jakarta.

Sodiq A \& Abidin Z. (2008). Meningkatkan Produksi Susu Kambing Peranakan Etawa. [e-book] Jakarta: PT Agromedia Pustaka.

http://books.google.co.id/books. Nov 2010].

Soekartawi. (1995). Analisis Usaha Tani. Jakarta : UI Press.

Zulfanita. (2011). Kajian Analisis Usaha Ternak Kambing Di Desa Lubangsampang Kecamatan Pituruh Kabupaten Purworejo. MEDIAGRO 7(2): 61-68. 